\title{
Fixed income mutual fund performance during and after a crisis: a Canadian case
}

\author{
Laleh Samarbakhsh $^{1}$ - Meet Shah ${ }^{1}$
}

Accepted: 3 February 2021 / Published online: 4 March 2021

(C) Academy of Economics and Finance 2021

\begin{abstract}
This study investigates the performance of the fixed income mutual funds industry, focusing on Canadian fixed income funds before, during, and after the 2008 global financial crisis. After recessionary shocks, investors look for ways to diversify their systematic risks. We investigate Canadian fixed income funds' excess returns and dollar fund flow and show that the funds significantly underperform bond markets throughout the study period after controlling for fund characteristics and macroeconomic factors. Consistent with previous studies, we find that this underperformance is more apparent during market downturns. Indicating a spiral relationship, these results suggest that institutional investors perform poorly during financial crises, which is also observable in the volatility patterns in dollar fund flow. We also find that the flow is positively related to the crisis period, indicating that the dollar fund flow in fixed income funds reported a positive value during the recession, signifying an inflow.
\end{abstract}

Keywords Financial crisis $\cdot$ Fixed income $\cdot$ Fund flow $\cdot$ Mutual fund

JEL classification $\mathrm{C} 32 \cdot \mathrm{G} 11 \cdot \mathrm{G} 31$

\section{Introduction}

Mutual funds are portfolios of various financial securities selected by professional fund managers. These funds ensure that the risk factor of their portfolios matches the risk preferences of the investors. A fixed income balanced fund must invest a minimum of

Laleh Samarbakhsh

1samarbakhsh@ryerson.ca

Meet Shah

meet2.shah@ ryerson.ca

1 Ted Rogers School of Management, Ryerson University, 350 Victoria St, Toronto, ON M5B

2K3, Canada 
$70 \%$ of total net assets in Canadian equity and fixed income securities. Of that $70 \%$, fund managers must allocate no more than $40 \%$ of assets into equity holdings. As this portfolio combines both equity and debt securities, it is intended for investors with lowto-medium risk preferences. As all mutual funds aim to yield positive returns on investments, mutual fund managers try to use strategies that can outperform standard indexes over specific periods. Various equity funds include other index funds or a combination of small/large capitalization stock. By contrast, debt funds include corporate or government bonds as well as fixed income and gilt funds. ${ }^{1}$ The strategies vary according to the individual risk preferences. Investors around the world have different beliefs about risk. Risk-seeking investors invest in riskier assets with a higher beta ${ }^{2}$ than the market, whereas risk-averse investors may invest in safer securities with a lower but guaranteed rate of return (e.g., GICs). As part of a diversification strategy, managers often invest in different asset classes and different geographic locations to reduce the overall risk of the portfolio, often referred to as "systematic risk." The literature has analyzed the contributions made by various parameters of international funds, such as asset and fund size, management expenses, strategies, investment performance, and fees (Ippolito 1989; Cumby and Glen 1990; Droms and Walker 1994). Many U.S. mutual funds that invest abroad deal extensively with equity funds in developed nations but also invest a lesser share in transitional economies because of their higher default risk (Kaminsky et al. 2001). Investing in international mutual funds offers a practical way to diversify and earn the highest risk-adjusted return (Droms and Walker 1994).

The mutual fund industry averaged positive returns during the 2008 financial crisis (Bello 2008). The crisis affected the lives of many individuals around the world due to the collapse of the stock market, the burst of the housing bubble, the increased unemployment rates, and the significant drop in interest rates (Helppie 2011). Researchers were led to conclude that specific predatory trading techniques contributed to the crisis. Nevertheless, investors still managed to invest their funds in different markets domestically as well as internationally to diversify their risk and boost portfolio returns. Research dating back to the inception of mutual funds has examined a variety of angles concerning the mutual fund industry, from those who manage the funds (Aggarwal and Jorion 2010) to fund performance with respect to market indexes (Cumby and Glen 1990, Blake et al. 1993, Leite and Armada 2017). While research on equity funds has been accumulating, there remains little practical or academic knowledge on debt funds, such as fixed income funds in Canada. Fixed income funds are investments that pay a fixed rate of return on government bonds, corporate bonds, and other grade bonds. Debt funds have been growing at a higher rate than equity funds. ${ }^{3}$ Various global events have impacted financial markets and the lives of many, the most recent being the COVID-19 pandemic. Zenteno and Aquino (2020) claim that balanced and fixedincome funds suffered the most amongst all fund classes. Based on that observation, this study poses the following research question: How did the financial crisis impact the performance of Canadian fixed income funds? This question can help determine how

\footnotetext{
${ }^{1}$ Long-term debt trading funds that have an above-average risk profile.

${ }^{2}$ Risk of a stock based on the overall market. The greater the risk, the higher the beta.

${ }^{3}$ Investment Company Institute. 2019. "Annual Report for Members”. Accessed November 15, 2019. https:// www.ici.org/pubs/annuals.
} 
fixed income funds respond to crisis periods. Institutional investors can use this research to focus on allocation strategies during moments of distress.

Determining how fund flow varies for fixed income funds throughout recessionary periods allows this study to offer a good indication of the economic environment and depict levels of variation in returns that provide an accurate snapshot of the debt funds in the industry. Having clearer insight into fixed income funds in crisis periods allows investors, practitioners, and fund managers to construct portfolios that minimize risk during economic downturns. Identifying performance variations in a specific segment of the mutual fund industry requires that we first understand the overall nature of the mutual fund industry, so that we can better assess how the recession impacted the funds under examination.

The government of Canada weathered the global financial crisis because it prevented top banks from engaging in risky behavior. Due to such policies and the creation of strict regulatory reforms, banks in Canada were spared a total market collapse. For example, in the United States, the collapse of the Lehman Brothers was due primarily to mortgage-backed securities depreciating below their book value, which dried up liquidity in financial markets. Unlike in the United States and Europe, the Canadian economy was not at risk of insolvency. Our research focuses on Canadian mutual funds - specifically, fixed-income mutual funds-which are presumably protected from endogenous crisis factors due to government measures designed to help banks endure the crisis, leading to the stability of the economy during the post-crisis period.

This study examines the impact of flow-induced mutual funds trading in the fixed income market to see how changes in fund size differ between the pre- and post-crisis periods. The rest of the paper is organized as follows. Section 2 reviews the related literature. Section 3 describes the methodology used to conduct the empirical analysis. Section 4 examines the study's dataset and interprets the results of the empirical analysis. Finally, Section 5 concludes the paper by discussing the results and avenues for future research.

\section{Literature review}

Mutual funds are increasing every year. An ordinary investor with nominal capital can pool their money with other like-minded individuals in a managed, diversified basket of stocks and bonds. Few studies focus on debt funds, with equity funds receiving most of the interest in the literature. One type of study analyzes the performance of various categories of equity mutual funds (Aggressive Growth, Small Company, Growth, Growth and Income, Equity Income) during the recessions of 1990 and 2001. This type of study offers intuitive insights into the relationship between stock prices and the economic life cycle of a specific region. One theory, first proven by Moore (1983), posited that stock prices rose when an economy was in the expanding stages and declined when the economy entered a recession. Stock prices are a good economic predictor, but they can send misleading signals. With this in mind, investors shifted to common stocks from bonds when the economy was booming and did the opposite when the economy was suffering (Moore 1983). Mutual funds, or portfolios of funds, consist of small-capitalization stocks ${ }^{4}$ during the growth of an economy because the

\footnotetext{
${ }^{4}$ Small businesses that have a market cap between $\$ 300 \mathrm{M}$ and $\$ 2 \mathrm{~B}$, measured by the stock price and any outstanding shares.
} 
lower rates allow small businesses to capitalize on the opportunity to grow their businesses, which in turn helps boost the economy. When the economy is going through a recession, investors prefer to divert their holdings toward mutual funds that contain mostly large-capitalization stocks. ${ }^{5}$

Equity mutual funds have shown greater returns in post-recessionary periods than they did in the recessionary period of 1990. However, in 2001, both the S\&P500 Index and mutual funds experienced negative returns during and after the recession. Mutual funds earned a higher return on funds that included a variety of small market cap stocks than did the market both during the recession and in the post-recession period (Bello 2008). This is a consistent finding in studies that have examined the relationship between stock prices and economic stages. The creation of a model that emphasizes the effects of equity funds in various economic states led to studies proving that equity funds typically perform better during recessions than during expansionary periods (Glode 2011). The question remains whether these patterns continued in the most recent financial crisis of 2008.

Mutual funds have the ability to diversify in various ways and still thrive in downturn economies. A risk-averse mutual fund investor would be more inclined to invest in a collection of low-risk securities such as bond funds. According to the Investment Company Institute (2019), bond mutual funds hold nearly $22 \%$ of total net assets, whereas equity mutual funds hold nearly $43 \%$ (Investment Company Institute 2019). Measuring the performance of bond-related mutual funds could prove helpful, as it would further our understanding of the nature of debt instruments in portfolios. However, bond funds can exceed investor expectations (Clare et al. 2019) or perform below the measured index (Blake et al. 1993).

The findings so far have reached no consensus. Thus, it is important to better understand the relationship between bond mutual funds and other similar factors. The relationship a bond mutual fund has with its fund characteristics (e.g., asset size, expense fees, trading strategies/objectives) is like that of equity funds. Like other funds, bond funds were also exposed to volatility during the global crisis, but this was the result of managers' inability to act according to recessionary signs (Clare et al. 2019). A multi-factor model allowed the analysis of bond mutual funds leading up to the financial crisis (Clare et al. 2019). Removing error biases, the model led to the argument that bond funds experienced higher returns before the crisis than after. Granted that models are imperfect, but studies have shown strong evidence of performance skewness during hard economic times, when both bond and equity mutual funds were exposed to various risk factors (Clare et al. 2019).

Leite and Armada (2017) find that bond funds significantly underperformed the markets during the financial crisis in Europe. At the same time, however, Europe also experienced the euro sovereign debt crisis, which affected the performance of mutual funds. Bond mutual funds performed better than the market at various economic periods, leading to the possibility that the drastic fluctuations caused the skewness. Leite and Armada (2017) find that the performance of bond funds continued to improve during the euro sovereign debt crisis. The U.S. pattern was different from that in Europe: U.S. bond funds experienced greater alphas in the post-crisis period than in the pre-crisis period for all maturity sectors (Clare et al. 2019). Most debt-driven

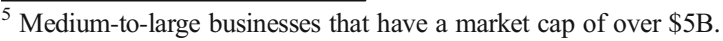


performance funds use the Capital Asset Pricing Model (CAPM) ${ }^{6}$ to price bonds. The CAPM model can prove how low-grade ${ }^{7}$ bond mutual funds match the performance of high-grade bond funds over a longer period (Cornell and Green 1991). European bond markets have also shown how the past performance of bond funds can repeat (Huij and Derwall 2008). This study offers further analysis to compare recessionary impacts on bond performance in various transitional periods.

International funds include a basket of securities from different asset and sector classes from around the world. They allow investors and mutual fund managers to diversify and reduce the systematic risk of their portfolios. Many international mutual funds are compared via specific international indexes like the $\mathrm{EAFE}^{8}$ or domestic indexes like the S\&P 500 (Droms and Walker 1994). A more complex and niche study might look at combinations of two different indexes, like the Morgan Stanley World Index and Euro currency deposits (Cumby and Glen 1990). The literature has analyzed such international fund parameters as asset and fund size, expenses, strategies, investment performance, and fees (Ippolito 1989; Droms and Walker 1994; Cumby and Glen 1990). Many U.S. mutual funds that invest abroad deal extensively with equity funds in developed nations but also invest a lesser share in transitional economies because of the higher default risk (Kaminsky et al. 2001). Investing in international mutual funds offers a practical way to diversify and earn the highest risk-adjusted return (Droms and Walker 1994). This is demonstrated by Grinblatt's, Titman's, and Jensen's measurements (Cumby and Glen 1990) used to check international fund performance against different benchmark indexes. Grinblatt and Titman's theories add a timing measure that allows the model to show how different asset classes perform with added information.

In theory, an investor who can foresee the future of the economy will invest in funds and earn a better return than an investor who cannot. Investors could buy equity funds if they expect stock prices to increase. The opposite is true when an increase in interest rates is observed, which leads investors to switch from equity to debt funds (Edwards and Zhang 1998). International funds performed better than the average in 1987 until October, when a sudden unexpected shock caused the stock market to crash. As a result, international funds suffered all around the world except in the Japanese market (Cumby and Glen 1990).

International mutual funds are used as a proxy in many studies to determine whether international fund indices make up an efficient market. ${ }^{9}$ This shows that investors seeking to diversify their holdings would need to include international mutual funds to support a well-balanced portfolio of assets, regardless of the fund class. In the U.S. market, investors choose to invest in low-fee funds and not in actively managed funds ${ }^{10}$ (Otten and Bams 2002). However, these findings contradict the market growth in

\footnotetext{
${ }^{6}$ This model is used to price assets given their current risk level. It measures the expected return on an asset given the market risk-free rate and the market risk premium.

${ }^{7}$ Low-grade mutual funds must have most of their portfolio invested in corporate bonds rated BAA or lower by Moody's or by Standard \& Poor's Index. In this case, bonds classified as low-grade have higher yields because the risk of default is higher. (The opposite is true for high-grade rated bonds.)

${ }^{8}$ Index used to compare performance outside of North America. EAFE stands for "Europe, Australasia, Far East."

${ }^{9}$ Market efficiency is reached when the market has the knowledge necessary to evaluate the prices of stocks. This would mean that stocks are neither undervalued nor overvalued.

${ }^{10}$ Active managed funds are those in which a manager or team of managers makes regular decisions to invest funds for their clients.
} 
Europe, which garnered much attention during the early 2000s, when researchers used that period to analyze the stock market of booming countries within Europe.

This study helps close the gap in the literature on debt funds, primarily that on fixed income funds. The literature is strongly focused on equity-based fund performance, whereas this study examines the recessionary impact on Canadian fixed income funds. As mentioned, the literature on equity funds describes the relationships affecting equity mutual funds on a macro-economic level. By contrast, the literature on bond mutual funds has grown but has failed to establish whether the financial crisis of 2008 affected the performance of Canadian fixed income funds. This study also investigates the size and performance of bond funds to decide if investors are, in fact, investing in bond funds to ensure more security in their investments.

\section{Methodology}

This study uses a thorough empirical method to analyze whether the financial crisis led to a significant change in fund flow within specific Canadian fixed income funds. The data consist of funds that have performed both well and poorly. Failure to use funds that were dropped by fund managers due to poor performance may result in survivorship bias, which affects the economic significance (Elton et al. 1996) of equity mutual funds. However, the performance bias has no effect on closed-end mutual funds relative to open-ended mutual funds (Bers and Madura 2000). Moreover, as new managers use funds during various periods, back-fill bias may skew the results at times. With the rise of new fixed income funds, managers can be provoked to give out information about funds that have shown better-than-average performance. However, Del Guercio and Tkac (2002) explain that neither of the biases affects flow or performance dramatically.

This study measures the performance of mutual funds as the average monthly return and total net assets. We use dollar fund flow to identify the relationship between fund performance and the inflow/outflow of funds within a fixed income fund group on a monthly basis. Previous studies focus on percentage fund flow (Cao et al. 2008, Rakowski 2010), but this study uses the standard definition employed in the literature. Equation (1) denotes the change in total net assets minus appreciation (Del Guercio and Tkac 2008; Kolokolova et al. 2020). Using this allows for a concise analysis of monthly net flow in Canadian fixed income funds. This definition of fund flow assumes that the flow occurs at the end of the month. Dflow $w_{i, t}$ is the monthly net dollar fund flow at time $t$ to an individual mutual fund $i$ :

$$
\text { Dflow }_{\boldsymbol{i}}=T N A_{i, t}-\left(\mathbf{1}+\operatorname{Ret}_{i, t}\right)\left(T N A_{i, t-1}\right)
$$

where $\operatorname{Ret}_{i, t}$ is the monthly return of a mutual fund at a point in time, and $T N A_{i, t}$ represents the corresponding total net assets. Therefore, flow is the difference between total net assets at time $t$ and the relationship of a one-month lag of total net assets $(t-1)$ scaled with the monthly return of the fund at time $t$. The linear model will enable further insight into how well fixed income funds perform. Comparing the dollar fund flow to a bond index return like that of a bond index is helpful because it directs further analyses toward a benchmark while measuring the change in flow size. Total net assets is a key indicator for determining the change of overall fund size. The monthly return is another 
performance measure that allows investors to compare the returns of different assets across different time periods. This study's analysis is broken down into three time periods: Q1.2000-Q2.2007 (pre-crisis), Q3.2007-Q2.2009 (during-crisis), and Q3.2009-2018 (after-crisis) (Bedendo and Bruno 2012). The goal is to determine if a significant change to fund flow occurred as a result of the 2008 financial crisis. The following hypothesis and null hypothesis are suggested:

Ha: There is a higher dollar fund flow in fixed income funds after the 2008 financial crisis than during the crisis.

Ho: The 2008 financial crisis did not have an impact on the dollar fund flow of fixed income funds.

The dataset comprises a collection of funds from 2000 to 2018 compartmentalized into three classes: Asset, Sector, and Geography. ${ }^{11}$ These categories enable different analyses of funds intended to develop a better understanding of the nature of fixed income funds. This study focuses on Canadian fixed income funds. No study has yet provided evidence on the fixed income market in Canada. Thus, the study examines how mutual fund performance varied across periods using comparisons with bond indexes and other Canadian mutual funds. Using key statistical analysis is important for understanding and evaluating the recessionary effects on mutual funds. The study first uses summary and descriptive statistics to acquire a broader understanding of the mutual funds and macroeconomic variables (e.g., monthly return, fund flow, change in total net assets) and enable an evaluation of the funds on a month-to-month basis. Next, an OLS regression analysis determines the statistical significance of the monthly return and dollar fund flow with the corresponding mutual fund and macroeconomic variables. Various models are used to clearly determine the variability of monthly return and dollar fund flow. The study conducts a time series analysis to examine the trends of fixed income bonds compared to short- and long-term bond indexes in the three study periods (pre-recession, during the recession, and post-recession). The time series notes the difference in fund sizes and compares among the returns to evaluate the performance across economic stages. The data analysis merges the data based on a unique fund ID. The data are retrieved from Fundata Inc., Statistics Canada, and the Bank of Canada.

\section{Data and empirical results}

The dataset from Fundata Inc. is the primary source for the data used in the analysis on mutual funds, including monthly returns, management fees, fund allocation, and operating expenses for all fixed income funds from 2000 to 2018. Over the sample period, the number of bond funds increased significantly. Of the 30,470 unique funds, this study focuses on fixed income funds in Canada to determine the recession's impact on performance during and after the 2008 financial crisis. The last sample contains 2493 unique funds as of September 2018. The funds are then divided into six categories: (i) Canadian fixed income, (ii) Canadian fixed income balanced (iii)

\footnotetext{
${ }^{11}$ See Exhibit A in the Appendix for a breakdown of categories.
} 
Canadian short-term fixed income, (iv) Canadian corporate fixed income, (v) Canadian inflation-protected fixed income, and (vi) Canadian long-term fixed income. In addition to Canadian fixed income funds, we also compare the effects of the financial crisis on Canadian equity and global fixed income funds. ${ }^{12}$ Investors used to be limited in their choices of investments in heavy-bond funds in Canada. Due to the recession, the industry changed dramatically. First, the need for diversification in the new issue bond market greatly increased the supply of bond-driven funds. Second, rising interest rates and several severe economic shocks sharply increased the number of "safe" securities. As a result, debt-driven bonds now account for $8.18 \%$ of the fixed income dataset.

Macroeconomic factors are used to assess fund performance with reference to a relative index. Three-month (short-term) and 10-year (long-term) yields (Bank of Canada 2019) are chosen to proxy for the Canadian bond index. The winsorization technique is implemented to ensure the statistical efficiency of the data. This method of eliminating spurious outliers allows us to readjust the mean and variance of the data. In the dataset, values associated with monthly return, total net assets, and management expense ratio (MER) account for a large quantity of extreme outliers. Therefore, following Kolokolova et al. (2020), we winsorize the lower and upper 1\% to reduce the influence of any extreme values. Summary statistics for the fixed income mutual fund and bond yields are provided in Table 1. Panel A reports the descriptive statistics of short- and long-term bond yields. The average return on a long-term bond is 1.7 times greater than that of a short-term government bond (3.40\% vs. $2.00 \%)$. The standard deviation is lower for the long-term bonds than for the short-term bonds $(1.42 \%$ vs. $1.53 \%)$. Bonds, like other trading instruments, carry some degree of risk. Long-term investments are associated with volatility (standard deviation), where shortterm investments may be subject to purchasing power risk. With long-term investments, market variability can lead to uncertainty in investments, causing funds to lose value. For short-term investments, however, the return is valued less than the future value as a result of inflation, suggesting that returns lag the inflation rate.

The sample period covers 19 years, from January 2000 to September 2018. It also includes time-series data on monthly returns, dollar fund flow, MER, and TNA. Panel $\mathrm{B}$ of Table 1 displays the descriptive statistics of the key variables in the sample. The fixed income funds category shows a minor positive average of returns of $0.003 \%$ with a standard deviation of $0.011 \%$. The total net asset size of fixed income funds is $\$ 300.22 \mathrm{M}$, with a standard deviation of $\$ 1030.07 \mathrm{M}$. The standard deviation is extremely high for the funds in the assets because of the significant change in flowspecifically, the fund inflow and outflow throughout the period. On average, the MER is $1.34 \%$, with a standard deviation of $0.64 \%$. Figure 1 depicts the relationship between bond indexes, fixed income funds, and median fund flow by displaying the trend over time. There are two scale measures; the primary axis (left-hand side) is measured in percentages, while the secondary axis (right-hand side) measures the flow in millions of dollars. The fixed income return is much smaller than that of the government bond yield, but this allows for a visual representation of the variation in returns.

The pattern indicates that the dollar fund flow displayed higher volatility leading up to the crisis period and eventually leveled out to a more stable flow. During the early period, flow fluctuations were abnormally higher than the later periods. During the

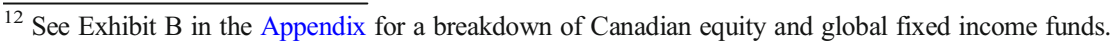


Table 1 Descriptive statistics

\begin{tabular}{|c|c|c|c|c|c|c|c|}
\hline & Mean & Median & STD & $\begin{array}{l}25 \text { th } \\
\text { Percent }\end{array}$ & 75th Percent & Min & Max \\
\hline \multicolumn{8}{|c|}{ Panel A: Macroeconomic } \\
\hline Cdn Gov3M-BY (\%) & 2.00 & 1.20 & 1.53 & 0.88 & 2.88 & 0.17 & 5.68 \\
\hline Cdn Gov10Y-BY (\%) & 3.40 & 3.39 & 1.42 & 2.09 & 4.50 & 1.00 & 6.54 \\
\hline TSX Index & $11,717.29$ & $12,210.70$ & 2794.65 & 9251.99 & $13,937.04$ & 6180.42 & $16,434.01$ \\
\hline \multicolumn{8}{|c|}{ Panel B: fixed income fund data } \\
\hline TNA (\$M) & 300.22 & 11.40 & 1034.07 & 1.76 & 88.54 & 0.00 & 7343.52 \\
\hline Log TNA & 2.34 & 2.43 & 3.18 & 0.56 & 4.48 & -6.92 & 8.90 \\
\hline Monthly Return (\%) & 0.003 & 0.002 & 0.011 & -0.003 & 0.008 & -0.031 & 0.034 \\
\hline $\operatorname{MER}(\%)$ & 1.34 & 1.37 & 0.64 & 0.89 & 1.84 & 0.01 & 2.66 \\
\hline Dollar Flow (\$M) & -35.31 & 0.01 & 1712.64 & -45.86 & 47.70 & $-18,988.56$ & 7343.52 \\
\hline
\end{tabular}

This table reports the descriptive statistics of the data from 2000 to 2018 . Panel A reports the macroeconomic variables expressed as monthly values. The 3-month and 10-year Government Bonds are monthly returns, stated in percentages. TSX Index is an index that provides investible opportunities and serves as a benchmark. Panel B describes the characteristics of Fixed Income Fund samples; Total Net Assets (TNA), Fund return (Monthly Return), Management Expense Ratio (MER), and the Dollar Fund Flow (Dollar flow). Panel A reports the descriptive statistics of short and long-term bond yields. The average return on a long-term bond is 1.7 times larger than the short-term government bond (3.40\% vs. $2.00 \%$ ), where the standard deviation of $3 \mathrm{M}$ bonds is 1.07 times greater than $10 \mathrm{Y}$ bonds ( $1.53 \%$ vs. $1.42 \%)$. When conducting summary statistics, outliers were present and affected the mean and variance of data. The winsorization technique is used to help deal with outliers as well as improve the statistical efficiency of the results. Panel B of Table 1 presents the descriptive statistics of the key fund characteristic of the sample. The fixed income funds category shows a minor positive average of returns of $0.003 \%$ with a standard deviation of $0.011 \%$. The average fund size is $\$ 300.22 \mathrm{M}$, with a standard deviation of $\$ 1034.07 \mathrm{M}$

crisis period, defined by Bedendo and Bruno (2012) as the period between Q3.2007Q1.2009, a significant drop in both short-term and long-term bonds is clear; however, the returns did not fall below $0 \%$. The short-term bonds experienced the greatest drop during the financial crisis because of the bonds' maturity factor. Relative to the government bond indexes, fixed income funds show minimal returns and a large volatility spread during the crisis period. Long-term bond yields steadily declined after 2001, implying that the value of a bond suffers over time due to various uncontrollable macroeconomic factors. We further analyze the dollar fund flow figures within various categories of mutual funds to assess changes in behavior amongst them. Figure 2 displays the average monthly dollar fund flow of Canadian fixed income, Canadian equity, and global fixed income funds. Naturally, we see peaks and troughs in each category, reflecting market ups and downs.

At the start of the financial crisis, we see an insignificant change in the flow of Canadian fixed income funds, but we see a greater outflow in Canadian equity and global fixed income funds. In the same figure, we see a slight impact of the "taper tantrum" on the flow of Canadian and global mutual funds. As the pace of bond purchases in the United States slowed, less money was being infused into the economy, resulting in less flow. The effects of the U.S. policy are seen to influence the behavior of Canadian mutual funds. Figure 2 shows the change in flow during different crisis 


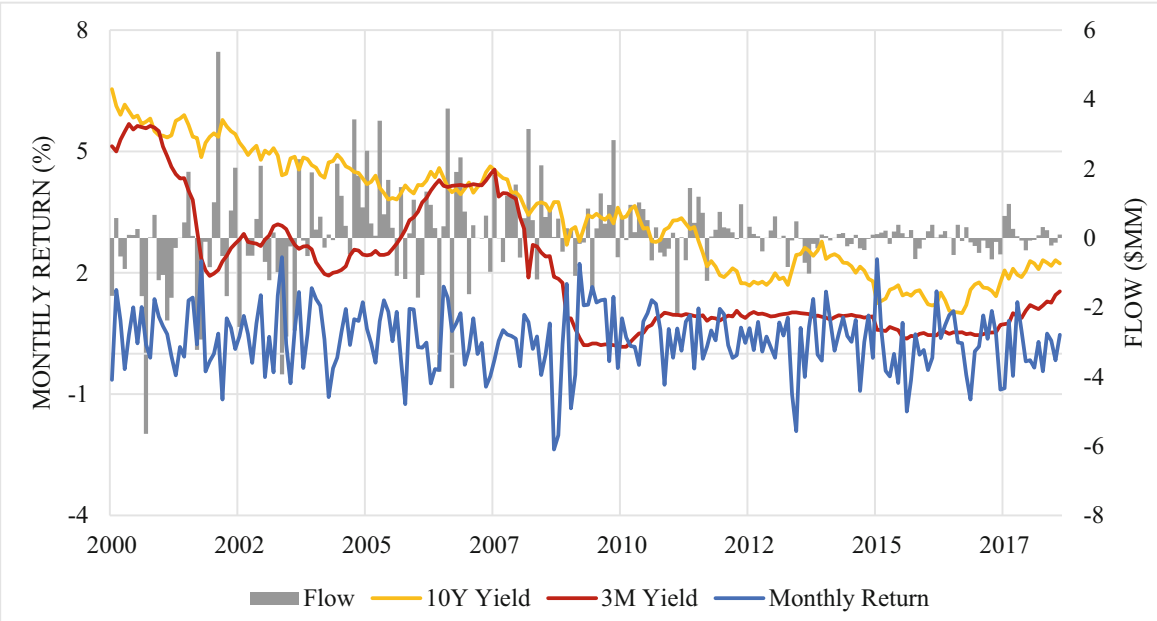

Fig. 1 Flow and return 2000 to 2018. Rate of Monthly Returns compared to the ten year (10Y) bond, three month (3M) Bond indexes, and median Fund Flow. The figure plots the average rate of return for Fixed Income Funds and Bond yields from 2000 to 2018 against the primary axis (left-side). The blue line represents the return of Canadian Fixed Income Funds. The red line is the three month Government Canadian Bond Yields. And the yellow line represents the ten year Government Canadian Bond Yield. The bar chart represents the median Dollar Fund Flow of Fixed Income Funds from 2000 to 2018 plotted against the secondary axis in \$MM (right-side). As the scales are different for yield and flow, it was necessary to plot the data differently for clarity and visual purposes. The average returns for the 10Y-Bond, 3M-Bond, and Fixed Income Fund are $3.40 \%, 2.00$ and $0.003 \%$, respectively. The average dollar fund flow is -35.31 \$MM, representing an outflow. Source: Fundata Canada Inc.; Statistic Canada (2019); Bank of Canada (2019)

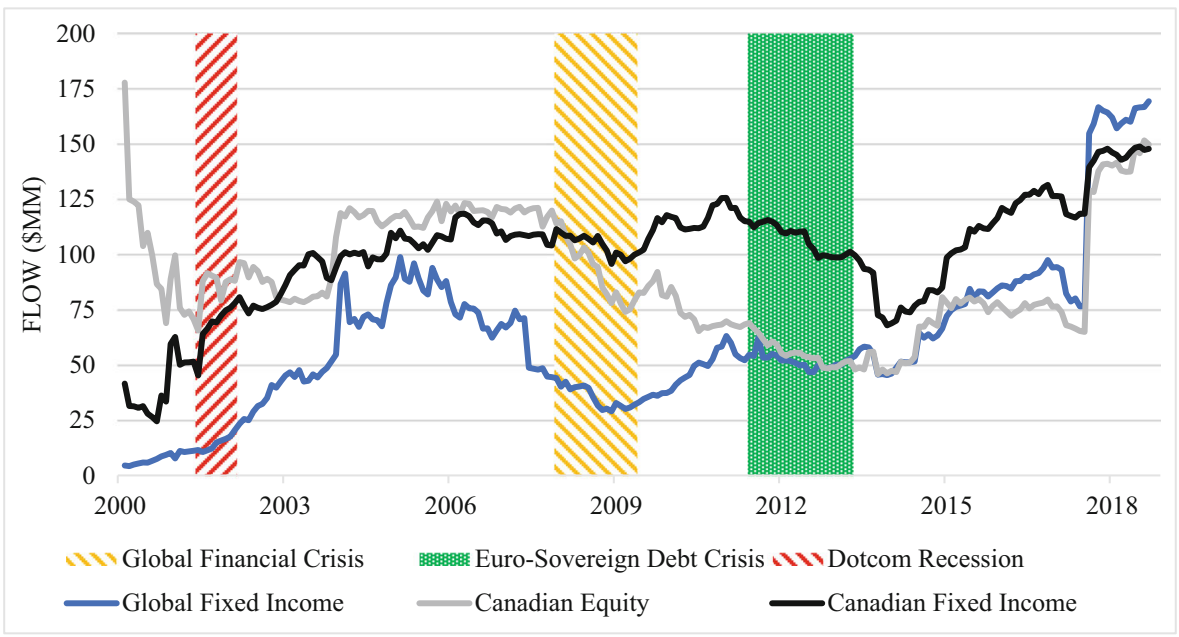

Fig. 2 Dollar fund flow comparison. This figure shows the average Dollar Fund Flow of all Canadian Fixed Income, Canadian Equity, and Global Fixed Income funds from January 2000-September 2018. The breakdown of each category can be found in the Appendix. The highlighted areas within the graphs indicate different crisis periods. The Dotcom bubble (Q2.2001 - Q4.2001), Global financial crisis (Q.42007; Bedendo and Bruno 2012), and Euro-Sovereign debt crisis (Q2.2011 - Q1.2013; Leite and Armada 2017). Relative to Canadian funds, we see Global Fixed Income funds experiencing a greater drop in fund flow during the financial crisis and the euro-sovereign debt crisis, but a greater increase during the dotcom bubble. Source: Fundata Canada Inc. 
periods from 2000 to 2018. We can see the fund flow variations for the subcategories of Global Fixed Income funds, Canadian Equity funds, and Canadian Fixed Income funds. We see instances of flow changing though economic distress periods such as Tech bubble aftermath, global financial crisis, and European debt crisis.

We filter the eligible fund flow data for Canadian fixed income, Canadian equity, and global fixed income funds. Then, we run a mean comparison t-test to determine the difference in flow between the two time periods (pre- and post-crisis). The results (see Table 2) suggest that there is a significant difference in fund flow between the two periods, as the $p$ value shows a significance level of less than $1 \%$. The greatest change is observed in Canadian equity funds, where the average flow is negative, signifying an outflow of funds after the financial crisis. Both fixed income categories saw positive flow (inflow) after the crisis, suggesting a change in behavioral patterns among institutional investors after financial distress. As bond prices fluctuate in volatile markets, high-quality bonds do not typically experience the price deviation one would expect to see in the stock market. In this study, most of the fixed income funds invest primarily in investment-grade fixed income securities, meaning that the credit quality of a healthy portfolio is BBB or higher.

Table 3 reports the descriptive statistics of monthly dollar fund flow in yearly format to illustrate the change in flow from year to year. The flow represents the dollar value increase or decrease based on positions held. In general, the dollar fund flow measures the positions held in various categories. The inflow bound by a positive value corresponds to an increase in the position, which is a component for net flow. For instance, Coval and Stafford (2007) find that mutual funds rely on the flow to determine positions held by investors in equity portfolios. One limitation of the calculations for this sample is the data disparity in 2018. In 2018, the fixed income funds reported monthly total net assets and returns near the end of September 2018. This may not seem like an important issue, but this selection bias may skew the data when scaled in a yearly format. Fund inflow represents an increase in position, meaning that an investor is buying more into the funds, and a fund outflow represents the opposite (Kolokolova et al. 2020). The average dollar fund flow for the Canadian fixed income funds only is

Table 2 Fund flow comparison between mutual fund categories

\begin{tabular}{lllllll}
\hline Dollar fund flow & No of funds & Pre-crisis & Post-crisis & Difference & T-Stat & Sig. \\
\hline Canadian fixed income funds & 2493 & 100.537 & 113.523 & 12.986 & 5.653 & $* * *$ \\
Canadian equity funds & 6277 & 109.527 & 82.808 & -26.719 & -21.647 & $* * *$ \\
Global fixed income funds & 2242 & 64.284 & 93.945 & 29.661 & 6.650 & $* * *$ \\
\hline
\end{tabular}

The table summarizes the average monthly Dollar Flow between Canadian Fixed Income, Canadian Equity, and Global Fixed Income mutual funds from January 2000 to December 2018. The breakdown of each category is available in the Appendix. The pre- and post-crisis periods are defined as Q1.2000-Q3.2007 and Q4.2007-Q4.2018, respectively (Bedendo and Bruno 2012). The use of t-tests is needed to measure the statistical significance of the monthly return and the size of each individual fund category. From this preliminary test, we see a significant decrease in fund flow for Canadian Equity Funds relative to other funds. $\mathrm{T}$-statistics are reported in parentheses. $* * *, * *$, and * indicate significance at the $1 \%, 5 \%$, and $10 \%$ levels, respectively

T-statistics reported in parentheses

$* p<0.1, * * p<0.05, * * * p<0.01$ 
Table 3 Annual summary statistic for dollar flow

\begin{tabular}{lll}
\hline Year & Flow & Std. Dev \\
\hline 2000 & 37.31 & 87.83 \\
2001 & 61.72 & 148.35 \\
2002 & 77.28 & 158.89 \\
2003 & 93.96 & 180.59 \\
2004 & 100.21 & 191.51 \\
2005 & 106.31 & 198.69 \\
2006 & 114.14 & 208.76 \\
2007 & 108.15 & 203.17 \\
2008 & 105.92 & 198.38 \\
2009 & 105.71 & 193.72 \\
2010 & 116.23 & 202.32 \\
2011 & 116.40 & 207.15 \\
2012 & 105.03 & 200.20 \\
2013 & 89.97 & 185.08 \\
2014 & 77.93 & 168.95 \\
2015 & 107.94 & 209.92 \\
2016 & 125.60 & 230.56 \\
2017 & 130.93 & 231.13 \\
2018 & 146.27 & 240.70 \\
Total & 112.50 & 210.78 \\
\hline
\end{tabular}

This table reports the monthly Dollar Fund Flow of Fixed Income Funds for the sample period of 2000-2018, scaled in a yearly format. A positive Flow value represents an inflow, and a negative Flow value represents an Outflow.Flow is calculated using a standard definition of the changes in total net assets minus appreciation (Del Guercio and Tkac 2008). The formula is as follows: DollarFlow $=T N A_{i, t}-\left(1+\right.$ MonthlyReturn $\left._{i, t}\right)\left(\operatorname{TNA}_{i, t}\right.$ $-1)$

112.50, implying that, on average, fixed income funds are increasing in size. The standard deviation is highest during the crisis period. The variation in fund flow indicates a change in holdings; the greater the standard deviation, the greater the change in fund size because of the constant inflow and outflow of funds. More institutional investors are adding fixed income funds in their portfolios to diversify some of the systematic risk they are exposed to through the equity funds.

To further analyze the fund flows within this context, we break them down to see if we find similar statistically significant correlations with returns. Table 4 reports the mean comparisons for fund flow and return for each fixed income fund during the two time periods (pre- and post-crisis, defined as Q1.2000-Q3.2007 and Q4.2007-Q4.2018 respectively; Bedendo and Bruno 2012). The Canadian fixed income subcategory is defined as follows: "Funds in the Canadian Fixed Income category must invest at least 90\% of their fixed income holdings in Canadian dollars with an average duration greater than 3.5 years and less than 9.0 years" (Canadian Investment Funds Standards Committee 2017). These saw increased flow after the global financial crisis, but the difference in means is not statistically significant. The dollar fund flow for each subcategory of Canadian fixed income funds was positive after the crisis, except for 
Table 4 Pre- and post-crisis: flow and return of canadian fixed income funds

\begin{tabular}{|c|c|c|c|c|c|}
\hline Panel A: Dollar Flow of All Fixed Income Funds & No of Funds & Pre-Crisis & Post-Crisis & Difference & Sig. \\
\hline Canadian Corporate Fixed Income & 111 & 13.811 & 119.764 & 105.953 & $* *$ \\
\hline Canadian Fixed Income & 1083 & 101.470 & 104.913 & 3.443 & \\
\hline Canadian Fixed Income Balanced & 865 & 91.452 & 129.918 & 38.466 & $* * *$ \\
\hline Canadian Inflation Protected Fixed Income & 82 & 193.007 & 111.906 & -81.101 & $* * *$ \\
\hline Canadian Long-Term Fixed Income & 24 & 28.216 & 139.330 & 111.114 & $* * *$ \\
\hline Canadian Short-Term Fixed Income & 375 & 92.934 & 92.698 & -0.236 & \\
\hline $\begin{array}{l}\text { Panel B: Monthly Return of All Fixed Income } \\
\text { Funds }\end{array}$ & No Of Funds & Pre-Crisis & Post-Crisis & Difference & Sig. \\
\hline Canadian Corporate Fixed Income & 111 & $0.37 \%$ & $0.23 \%$ & $-0.15 \%$ & $* * *$ \\
\hline Canadian Fixed Income & 1083 & $0.37 \%$ & $0.21 \%$ & $-0.16 \%$ & $* * *$ \\
\hline Canadian Fixed Income Balanced & 865 & $0.46 \%$ & $0.33 \%$ & $-0.14 \%$ & $* * *$ \\
\hline Canadian Inflation Protected Fixed Income & 82 & $0.33 \%$ & $0.27 \%$ & $-0.06 \%$ & \\
\hline Canadian Long-Term Fixed Income & 24 & $0.56 \%$ & $0.42 \%$ & $-0.14 \%$ & \\
\hline Canadian Short-Term Fixed Income & 375 & $0.27 \%$ & $0.11 \%$ & $-0.17 \%$ & $* * *$ \\
\hline
\end{tabular}

This table summarizes the average Monthly Dollar Fund Flow (Panel A) and Monthly Return (Panel B) of all Canadian Fixed Income Fund categories from January 2000 to December 2018. The pre- and post-crisis periods are defined as Q1.2000-Q3.2007 and Q4.2007-Q4.2018, respectively (Bedendo and Bruno 2012). Monthly return is winsorized at the $5 \%$ level at each tail to ensure statistical efficiency. The use of t-tests is needed to measure the statistical significance of monthly return and the size of each individual fund category. We see a convex relationship between flow and return on fixed income funds after the financial crisis. Tstatistics are reported in parentheses. ***, **, and * indicate significance at the $1 \%, 5 \%$, and $10 \%$ levels, respectively

T-statistics reported in parentheses

$* p<0.1, * * p<0.05, * * * p<0.01$

Canadian inflation-protected fixed income (-81.10) and Canadian short-term fixed income funds $(-0.236)$. The Canadian long-term fixed income fund saw the highest percentage increase in dollar fund flow after the financial crisis (111.114). For each subcategory, all fixed income funds experienced $0.13 \%$ lower monthly returns after the crisis. As fund flow for all fixed income funds increased, the monthly return decreased. The substantial increase in fund flow after the crisis is partly due to the crisis itself. Institutional investors are investing more in these mutual funds to help diversify some of the risks. Overall, we find evidence of significant differences among the Canadian fixed income fund categories. Over time, these funds experienced natural changes brought on by market conditions.

Table 5 reports a comparison of the monthly means of the Canadian fixed income fund return between the three time periods. We report a t-test of the two groups to determine statistical significance and fit. The full sample period is used as the base to compare the means. The mean return over time is positive, and we see a lower return during the post-crisis stage, when the spread is $(0.257 \%$ vs $0.243 \%) 1.4 \mathrm{bps}$. The return is relatively close to the median $(0.257 \%$ vs $0.247 \%)$, indicating that the returns are not affected by any outliers, and the data are marginally skewed to the right. The pre- and post-crisis periods are statistically significant at the $1 \%$ level, which is useful for developing the regression models. 
Table 5 Summary statistics on the returns of fixed income portfolio

\begin{tabular}{lllll}
\hline & Full period & Pre-crisis & During-crisis & Post-crisis \\
\hline Mean & $0.257 \%$ & $0.385 \%$ & $0.270 \%$ & $0.243 \%$ \\
Median & $0.247 \%$ & $0.367 \%$ & $0.414 \%$ & $0.231 \%$ \\
Std. Dev. & $1.062 \%$ & $1.053 \%$ & $1.498 \%$ & $1.023 \%$ \\
$\mathrm{~N}$ & 156,989 & 13,194 & 9773 & 134,022 \\
Test of difference in means & $-0.1283 \% * * *$ & $-0.013 \%$ & $0.0136 \% \%^{* * *}$ \\
& & $(-13.3311)$ & $(-1.1397)$ & $(3.4938)$ \\
\hline
\end{tabular}

This table summarizes the average monthly return of fixed income funds from 2000 to 2018 and provides a breakdown of the funds during three economic periods. The pre-, during-, and post-crisis periods are defined as Q1.2000-Q2.2007, Q3.2007-Q1.2009, and Q2.2009-Q4.2018, respectively (Bedendo and Bruno 2012). The winsorization technique is used to help deal with outliers and improve the statistical efficiency of the results. As the preliminary results indicate the anticipated negative returns during recessionary times, fixed income funds yield a greater return than during the pre- and post-stages. The use of $\mathrm{t}$-tests is needed to measure the statistical significance of monthly returns in different periods. The full sample period is used as the base to compare each period separately. The first difference of means is between the entire period and the pre-crisis period, the second is between the entire period and the during-crisis period, and the last is between the entire period and the post-crisis period. T-values are reported in parentheses. $* * *, * *$, and $*$ indicate significance at the $1 \%, 5 \%$, and $10 \%$ levels, respectively

The greatest variation in return is observed during the crisis period $(1.498 \%)$ because funds have much higher volatility during economic crisis periods than during expansionary periods (Leite and Armada 2017). The performance, as measured in terms of return, declines marginally over time. Regarding the timing indicators, the pre-crisis mean returns are 1.6 times greater than the returns in the post-crisis period. Investors may experience some gains but would also suffer an above-average market loss in the process. The observations during the post-crisis period account for $85 \%$ of the sample because of the number of funds that were created and filled after the crisis. The anticipated growth in fixed income funds following the crisis can be attributed to several factors, such as the capitalization of opportunity, which leads to macroeconomic uncertainty and the need for low-risk portfolios. The low-interest rates in Canada during the last 10 years ultimately led to the creation of new fixed income funds. As the interest rates decreased, the value of issued bonds increased. The increase in the rates of many debt funds induced investors and fund managers alike to take advantage of the opportunity.

The correlation analysis presented in Table 6 reports the pairwise correlation coefficients between variables in order to identify the numeric strength of the macroeconomic factors and key control variables. $P$-values are reported in parentheses. The correlation coefficient is shown between the average monthly return, dollar fund flow, management fee, mutual fund age, government bond indexes, and the TSX index. The dollar fund flow forms a weak positive correlation with the $10 \mathrm{Y}$ and $3 \mathrm{M}$ government bond indexes ( 0.001 vs. 0.006$)$ and is deemed to be statistically significant, contrary to the findings of Kolokolova et al. (2020). Although the coefficients are minuscule and point to no correlation, this result suggests that, as dollar fund flow increases for fixed income mutual funds, long- and short-term government yields also increase. The positive relationship between dollar fund flow and return indicates that, as the aggregate flow of the fund increases, the return also increases. However, the coefficient between fund flow and return is reported as a negative correlation $(-0.001)$ and is 
Table 6 Correlation analysis

\begin{tabular}{|c|c|c|c|c|c|c|c|}
\hline Variable & (1) & (2) & (3) & (4) & (5) & (6) & (7) \\
\hline (1) Flow & 1.000 & & & & & & \\
\hline (2) Total Net Assets & $\begin{array}{l}0.602 * * * \\
(0.000)\end{array}$ & 1.000 & & & & & \\
\hline (3) MER & $\begin{array}{l}-0.016^{* * *} \\
(0.000)\end{array}$ & $\begin{array}{l}-0.037 * * * \\
(0.000)\end{array}$ & 1.000 & & & & \\
\hline (4) Monthly Return & $\begin{array}{l}-0.001 \\
(0.857)\end{array}$ & $\begin{array}{l}-0.008^{* * *} \\
(0.007)\end{array}$ & $\begin{array}{l}0.002 \\
(0.492)\end{array}$ & 1.000 & & & \\
\hline (5) Long-term Bond & $\begin{array}{l}0.010 * * * \\
(0.004)\end{array}$ & $\begin{array}{l}-0.044 * * * \\
(0.000)\end{array}$ & $\begin{array}{l}0.104 * * * \\
(0.000)\end{array}$ & $\begin{array}{l}0.011 * * * \\
(0.000)\end{array}$ & 1.000 & & \\
\hline (6) Short-term Bond & $\begin{array}{l}0.006^{*} \\
(0.091)\end{array}$ & $\begin{array}{l}-0.021 * * * \\
(0.000)\end{array}$ & $\begin{array}{l}0.074 * * * \\
(0.000)\end{array}$ & $\begin{array}{l}-0.019 * * * \\
(0.000)\end{array}$ & $\begin{array}{l}0.752 * * * \\
(0.000)\end{array}$ & 1.000 & \\
\hline (7) TSX Index & $\begin{array}{l}-0.011 * * * \\
(0.002)\end{array}$ & $\begin{array}{l}0.045 * * * \\
(0.000)\end{array}$ & $\begin{array}{l}-0.120 * * * \\
(0.000)\end{array}$ & $\begin{array}{l}-0.081 * * * \\
(0.000)\end{array}$ & $\begin{array}{l}-0.583 \text { *** } \\
(0.000)\end{array}$ & $\begin{array}{l}-0.280^{* * * *} \\
(0.000)\end{array}$ & 1.000 \\
\hline
\end{tabular}

This table reports the pairwise correlation coefficients over time for the 2000-2018 sample period between the variables used in this study. Dollar Flow is the growth size of a specific fund; Total Net Assets is the monthly average used to measure the total value of a fund; MER is the Management Expense Ratio, which represents an associated fee for a fund; Monthly Return is the log return on fixed income funds in the dataset; TSX Index denotes the monthly average index values of the TSX Market; Long Term Bond is the 10-Year Government Bond index; Short Term Bond is the 3-Month Government Bond index, and Dollar Flow is the monthly dollar fund flow of fixed income funds. $P$-values are reported in parentheses. $* * * * *$, and $*$ indicate significance at the $1 \%, 5 \%$, and $10 \%$ levels, respectively

statistically insignificant. The significant correlations between the three macroeconomic variables (10Y Bond, $3 \mathrm{M}$ Bond, and TSX Index) reveal that bonds move in harmonious wavelengths with one another. As the TSX index increases, the correlation coefficients indicate a higher negative factor for long-term bonds as opposed to short-term bond yields $(-0.583$ and -0.280$)$. This may raise multicollinearity issues; however, they are not a concern because the index is used only in combination with all control variables when estimating the regression models.

Table 7 reports the estimation results for Eqs. (2), (3), and (4). As shown in Eq. (2), the dollar fund flow is regressed on the average monthly total net assets, monthly return, the monthly management expense ratio, and the age of the fund; the combination of macroeconomic short- and long-term bond yields and the market index is described in Eqs. (3) and (4):

$$
\text { Dollarflow }_{i, t}=\beta_{1}\left(\text { TNA }_{i, t}\right)+\beta_{2}\left(\text { MFRet }_{i, t}\right)+\beta_{3}\left(\operatorname{MER}_{i, t}\right)+\beta_{4}\left(\text { age }_{i, t}\right)+\varepsilon_{i}
$$

where MFRet represents the average monthly return of fixed income funds during the sample period, TNA is the average monthly total net assets during the sample period, $M E R$ is the average monthly fee deducted from the portfolio (also known as the "Management Expense Ratio"), and Age is a mutual fund characteristic reflecting the age of a fund from its date of inception. 
Table 7 Dollar fund flow regression

\begin{tabular}{|c|c|c|c|c|c|c|}
\hline & Model 1 & Model 2 & Model 3 & Model 4 & Model 5 & Model 6 \\
\hline Constant & $\begin{array}{l}-347.73 * * * \\
(-25.3)\end{array}$ & $\begin{array}{l}-356.65^{* * *} \\
(-25.75)\end{array}$ & $\begin{array}{l}-133.46^{* *} \\
(-2.27)\end{array}$ & $\begin{array}{l}-179.23 * * * \\
(-2.97)\end{array}$ & $\begin{array}{l}-134.11^{* *} \\
(-2.28)\end{array}$ & $\begin{array}{l}-179.85^{\text {*** }} \\
(2.98)\end{array}$ \\
\hline \multicolumn{7}{|c|}{ Mutual Fund Characteristics } \\
\hline TNA & $\begin{array}{l}0.99 * * * \\
(215.61)\end{array}$ & $\begin{array}{l}1.01 * * * \\
(218.41)\end{array}$ & $\begin{array}{l}0.99 * * * \\
(215.93)\end{array}$ & $\begin{array}{l}1.01 * * * \\
(218.6)\end{array}$ & $\begin{array}{l}0.99 * * * \\
(215.93)\end{array}$ & $\begin{array}{l}1.01 * * * \\
(218.60)\end{array}$ \\
\hline MFRet & $\begin{array}{l}705.63 \\
(1.47)\end{array}$ & $\begin{array}{l}447.26 \\
(1.92)\end{array}$ & $\begin{array}{l}335.39 \\
(0.70)\end{array}$ & $\begin{array}{l}256.83 \\
(0.53)\end{array}$ & $\begin{array}{l}334.95 \\
(0.70)\end{array}$ & $\begin{array}{l}257.11 \\
(0.53)\end{array}$ \\
\hline MER & $\begin{array}{l}18.75^{* * *} \\
(2.41)\end{array}$ & $\begin{array}{l}15.15^{*} \\
(1.92)\end{array}$ & $\begin{array}{l}6.09 \\
(0.78)\end{array}$ & $\begin{array}{l}6.68 \\
(0.84)\end{array}$ & $\begin{array}{l}6.04 \\
(0.77)\end{array}$ & $\begin{array}{l}6.64 \\
(0.84)\end{array}$ \\
\hline Age & $\begin{array}{l}-0.01 * * * \\
(-3.02)\end{array}$ & $\begin{array}{l}-0.01 * * \\
(-2.04)\end{array}$ & $\begin{array}{l}0.002 \\
(0.42)\end{array}$ & $\begin{array}{l}0.001 \\
(0.18)\end{array}$ & $\begin{array}{l}0.002 \\
(0.42)\end{array}$ & $\begin{array}{l}0.001 \\
(0.84)\end{array}$ \\
\hline \multicolumn{7}{|c|}{ Macroeconomic variables } \\
\hline 10Y Bond & & & $\begin{array}{l}50.95^{* * * *} \\
(5.03)\end{array}$ & $\begin{array}{l}49.77 * * * \\
(4.78)\end{array}$ & $\begin{array}{l}49.98^{* * * *} \\
(4.89)\end{array}$ & $\begin{array}{l}49.05 * * * \\
(4.68)\end{array}$ \\
\hline $3 \mathrm{M}$ Bond & & & $\begin{array}{l}-20.933 * * \\
(-2.28)\end{array}$ & $\begin{array}{l}-20.79 * * \\
(-2.22)\end{array}$ & $\begin{array}{l}-21.38^{* *} \\
(-2.33)\end{array}$ & $\begin{array}{l}-21.18^{* *} \\
(-2.26)\end{array}$ \\
\hline TSX & & & $\begin{array}{l}-0.023^{* * * *} \\
(-6.83)\end{array}$ & $\begin{array}{l}-0.0195 * * * \\
(-5.65)\end{array}$ & $\begin{array}{l}-0.022^{* * *} \\
(-6.76)\end{array}$ & $\begin{array}{l}-0.019 * * * \\
(-5.59)\end{array}$ \\
\hline Crisis & & & & & $\begin{array}{l}17.15 \\
(0.73)\end{array}$ & $\begin{array}{l}14.25 \\
(0.59)\end{array}$ \\
\hline Fixed Effects & - & Yes & - & Yes & - & Yes \\
\hline Adj- $R^{2}$ & $37.77 \%$ & $37.77 \%$ & $37.92 \%$ & $37.92 \%$ & $37.92 \%$ & $37.92 \%$ \\
\hline $\mathrm{N}$ & 77,725 & 77,725 & 77,725 & 77,725 & 77,725 & 77,725 \\
\hline
\end{tabular}

The table presents the results of the OLS regressions explaining the monthly dollar fund flow of unbalanced Fixed Income Mutual Funds from 2000 to 2018. Fixed Effect estimation is used to control for variables to avoid collinearity within the unbalanced sample data. Here, Dflow is the dependent variable of the monthly flow of fixed income funds; TNA is the monthly average of Total Net Assets; MFRet is the average monthly return of an individual fund; $M E R$ is the average monthly Management Expense ratio indicating an associated fee; $10 \mathrm{Y}$ bond is the monthly average yield of the Canadian 10-Year maturity bonds; $3 \mathrm{M}$ bond is the monthly average yield of the Canadian 3-Month maturity bonds; and the TSX is the monthly index performance for the TSX Composite Index. Crisis is a dummy variable taking a value of 1 from Q3.2007-Q1.2009 (Bedendo and Bruno 2012) and 0 otherwise. The bond yield data are obtained from the Bank of Canada (Bank of Canada 2019) website, and the TSX index data are retrieved from the Government of Canada (Statistics Canada 2019). P-values are given in parentheses. $*, * *$, and $* * *$ indicate significance at $1 \%, 5 \%$, and $10 \%$ levels, respectively. The general baseline model is given by the equation below: $\operatorname{Dflow}_{i, t}=\beta_{1}\left(\right.$ TNA $\left._{i, t}\right)+\beta_{2}\left(\right.$ MFRet $_{i}$, $\left.{ }_{t}\right)+\beta_{3}\left(M E R_{i, t}\right)+\beta_{4}(A g e)+\varepsilon_{i}$

$$
\begin{aligned}
\text { Dollarflow }_{i, t}= & \beta_{1}\left(\text { TNA }_{i, t}\right)+\beta_{2}\left(\text { MFRet }_{i, t}\right)+\beta_{3}\left(\text { MER }_{i, t}\right)+\beta_{4}\left(\text { Age }_{i, t}\right) \\
& +\beta_{5}\left(\text { 10YBond }_{t}\right)+\beta_{6}\left(3 \text { MBond }_{t}\right)+\beta_{7}\left(\text { TSXIndex }_{t}\right)+\varepsilon_{i}
\end{aligned}
$$




$$
\begin{aligned}
\text { Dollarflow }_{i, t}= & \beta_{1}\left(\text { TNA }_{i, t}\right)+\beta_{2}\left(\text { MFRet }_{i, t}\right)+\beta_{3}\left(\text { MER }_{i, t}\right)+\beta_{4}\left(\text { Age }_{i, t}\right) \\
& +\beta_{5}\left(\text { 10YBond }_{t}\right)+\beta_{6}\left(3 \text { MBond }_{t}\right)+\beta_{7}\left(\text { TSXIndex }_{t}\right)+\beta_{7}(\text { Crisis }) \\
& +\varepsilon_{i}
\end{aligned}
$$

where 10YBond and 3MBond are monthly average long- and short-term bond yields, respectively. Models (3) and (4) include the average monthly index figure, denoted by TSX Index. Models (5) and (6) use a dummy variable to control for the effects of the financial crisis. Models (1) and (2) include the control variables used to model dollar fund flow. All regression models are treated with fixed effects to exploit the anomalies within a certain subset of groups. OLS regression models may omit certain variables that are not time-invariant, and this would cause biases. Fixed effects incorporate all the characteristics of funds that do not change over time and include the effects of timeinvariant characteristics that are hard to measure. When macroeconomic interactions are included in models (3) to (6), the adjusted $\mathrm{R}^{2}$ increases by $0.20 \%$. Flow is positively related to total net assets and age when only fund characteristics are estimated. The coefficients from the OLS regression, followed by fixed effects in parentheses, of $0.99(1.01)$ and $-0.01(-0.01)$ are statistically significant at the $1 \%$ level. The interactions between the combination of age and flow, or of fees and flow, in model 3 are not statistically significant. However, they include market factors that are significant at the $1 \%$ and $5 \%$ levels. An additional increase of $50 \mathrm{bps}$ in long-term bonds results in an increase of 25.48 bps in fund flow. An increase of 50 bps in shortterm bonds results in a decrease in fund flow of $0.11 \mathrm{bps}$. The economic significance suggests that both government bond yields reflect the different nature of bond funds. To verify the robustness of the results, we examine the TSX index to evaluate the impact of the dollar fund flow on fixed income funds. The relationship between equity and bond markets has been noted in theory; the regression models suggest that, when the price of equity goes up, bond yields go down, forming an inverse relationship. With the increase in the TSX index, a proxy for equity markets, we observe an outflow of funds, indicating that the allocation of assets is being repositioned. This illustrates the foundational theory's suggestion that, as investors see a rise in equity markets, bond markets lose value, thus creating an outflow. Fund flows can reflect the risk preferences of investors and also provide context for the influence of investment decisions within the market (Kamstra et al. 2017).

We compare the regression estimates from Table 7 to those in Table 8 to measure the impact of the crisis on fixed income and equity funds. We find that the size of Canadian and global fixed income funds increased after the crisis to a much greater extent than Canadian equity funds, indicating a change in investing behavior. As mentioned, institutional investors invest more capital into fixed income mutual funds, thus strengthening the hypothesis that fund flow increases after the financial crisis. Inversely proportional in both periods, as the flow increases, monthly returns for Canadian fixed income funds decrease by $9.20 \%$, which is statistically significant at the $1 \%$ level. The opposite is true for Canadian equity funds, where a one standard deviation increase in flow increases returns by $39.58 \%$.

Table 9 shows the results for each sub-period to depict the impact of the variables on dollar fund flow. Most estimations are statistically insignificant, but we see the 
Table 8 Categorical dollar fund flow regression

Panel A: Pre-crisis

Canadian fixed income Funds

$\begin{array}{ll}\text { LogTNA } & \begin{array}{l}\text { 25.305*** } \\ (26.32)\end{array} \\ \text { MFRet } & -199.62 * * * \\ & (-3.08) \\ \text { MER } & -14.89 * * * \\ & (-5.46) \\ \text { 10Y Bond } & -13.24 * * * \\ & (-5.96) \\ \text { 3 M Bond } & 4.16 * * * \\ & (3.26) \\ \text { TSX } & 0.003 * * * \\ & (4.38) \\ \text { Constant } & 74.68 * * * \\ & (5.46) \\ \text { Fixed Effects } & \text { Yes } \\ \text { N } & 8277 \\ \text { Adj. R } & 18.00 \%\end{array}$

Panel B: Post-crisis

Canadian fixed income funds

LogTNA

$48.57 * * *$

(216.17)

MFRet $\quad-217.98 * * *$

$(-10.44)$

MER $\quad 4.42 * *$

(2.03)

10Y Bond $\quad-9.33 * * *$

$(-19.70)$

3 M Bond $\quad 0.079$

(0.14)

TSX $0.002 * * *$

(11.62)

Constant $\quad-17.40 * * *$

$(-4.07)$

Fixed Effects Yes

$\mathrm{N} \quad 95,605$

Adj - R R $^{2} \quad 34.20 \%$
Global fixed income Funds $33.674 * * *$

(16.68)

$-103.52$

$(-1.12)$

$-3.24$

$(-0.53)$

$-1.60$

$(-0.31)$

$10.42 * * *$

(3.40)

$-0.0001$

$(-0.07)$

$-29.54$

(-0.95)

Yes

1620

$18.73 \%$

Global fixed income funds $54.66 * * *$

(205.40)

$-40.94 *$

$(-1.77)$

$20.26^{* * *}$

(7.17)

13.48 ***

(19.17)

$-3.78 * * *$

$(-3.95)$

$0.003 * * *$

(8.98)

$-114.64 * * *$

(-18.83)

Yes

63,989

$42.99 \%$
Canadian equity Funds $43.588 * * *$

(75.65)

$-126.41 * * *$

$(-7.74)$

$-4.97 * * *$

$(-3.16)$

$-3.41 * * *$

$(-2.71)$

$3.56 * * *$

(4.75)

$0.002 * * *$

(5.74)

$-18.88^{* *}$

$(-2.40)$

Yes

22,308

$30.23 \%$

Canadian equity funds 49.73***

(390.01)

-76.38 ***

$(-11.57)$

$14.65 * * *$

(12.81)

-2.16 ***

$(-7.29)$

1.89 ***

(5.44)

$0.001 * * *$

(8.48)

-33.12 ***

$(-11.72)$

Yes

227,453

$41.37 \%$

The table presents the estimations of regression models explaining the monthly dollar flow of each Canadian Fixed Income, Canadian Equity, and Global Fixed Income mutual fund from 2000 to 2018. Fixed Effect estimation is used to control for variables to avoid collinearity within the unbalanced sample data. Panel A reports the estimates of the regression for funds during the pre-crisis period, whereas panel B reports the regression results for funds during the post-crisis period. The Crisis dummy variable takes the value of 1 from Q3.2007-Q4.2018 (Bedendo and Bruno 2012) and 0 otherwise. The bond yield data are obtained from the Bank of Canada website, and the TSX index data are retrieved from the Government of Canada (StatsCan). Tstatistics are in parentheses. *, **, and *** indicate significance at the $1 \%, 5 \%$, and $10 \%$ levels, respectively T-statistics reported in parentheses

$* \mathrm{p}<0.1, * * \mathrm{p}<0.05, * * * \mathrm{p}<0.01$ 


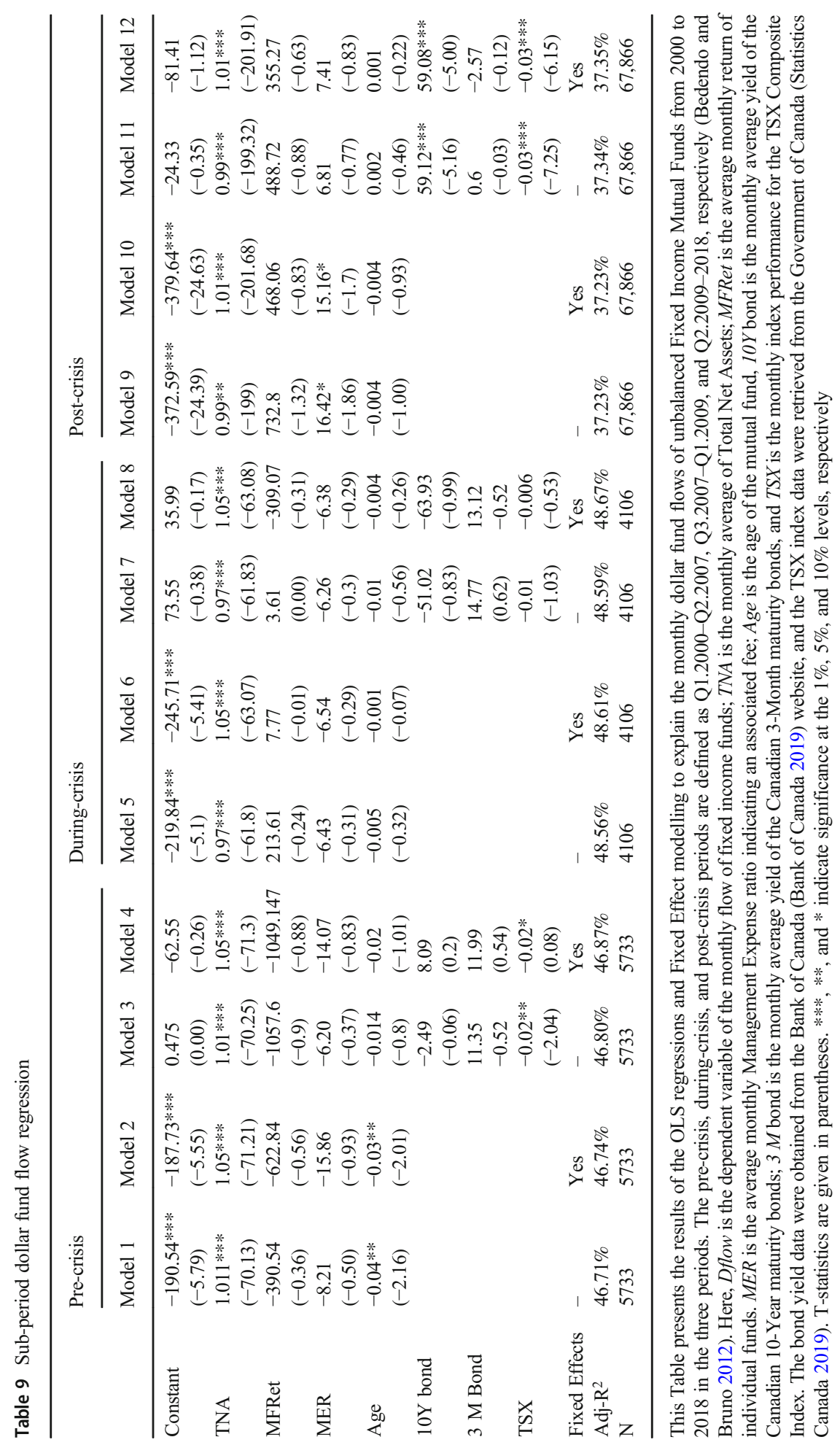


relationships between certain variables in specific periods. The results show that, during the post-crisis era, there are linkages between long-term bond yields and fund flow. The coefficient of 59.02 is statistically significant at the $1 \%$ level. Economically, as bond yields increase, estimates of the flow of funds also increase, implying a positive flow. This further proves that flow has a positive relationship with long-term bonds. In the first two stages (pre-crisis and during), the $\mathrm{R}^{2}$ increases by nearly $2 \%$ from $46.71 \%$ to $48.56 \%$, respectively, for the models that include mutual fund characteristics only. The same is observed when the macroeconomic variables are incorporated. This indicates that, during the recession, most portfolios and stocks experienced a loss in investments, despite the diversification strategies used (Helppie 2011). These findings are also consistent with those of earlier studies that have investigated recessionary impacts and have found that bond funds earn marginally higher returns during pre-crisis periods than they do afterwards (Clare et al. 2019). Not only did size increase after the crisis, but returns were marginally greater than zero, indicating gains on the holdings. However, there are several limitations to the study. One important limitation that may impact the findings on flow and return are the macroeconomic variables, which might account for the full impact of economic activity. For instance, including variables such as inflation or price of commodities as a proxy could enable a better adjustment for those outside factors in this model. Overall, there are strategies in place to diversify funds in different categories within fixed income funds.

Future studies on this topic could seek to determine the allocation breakdown within fixed income funds during the 2008 financial crisis. Incorporating seasonality studies of fund categories, like that of Kamstra et al. (2017), can help determine the changes in the asset allocation of Canadian fixed income funds. This would allow us to understand the composition of funds, and it would also enable further testing to examine investor sentiment. Further research on the flows of long- and short-term bonds could also provide an indication of how fixed income mutual funds impact government bonds and other debentures.

\section{Conclusion}

Our results show that, for the overall sample period, Canadian fixed income funds underperformed the bond markets. This underperformance is more apparent during recessionary periods than during economic expansion periods, but the bond fund returns are lower than the market average during both periods (Leite and Armada 2017). When evaluating the different stages, we find significant variation in fund flow leading up to the financial crisis as well as during the crisis. This suggests that institutional investors such as mutual funds act differently in periods of distress, which leads to patterns of volatility in fund flow. These findings are in line with Rakowski and Wang (2009), who suggest that variation in behavioral patterns are observed through fund flow. The change in Canadian fixed income funds indicates that investors are transitioning their holdings to other sectors or assets, which is observed through total net assets and fund flow.

In this study, DollarFlow is used to measure the interactions between mutual fund characteristics and macroeconomic variables during various states of the economy. 
Prior studies have focused on equity-driven funds, which outperformed more during the recession than they did during post-recession periods (Glode 2011). In contrast to debt-driven funds, these funds have been shown to experience higher returns before the crisis than after Clare et al. (2019). This study reinforces the finding that returns were higher in the pre-crisis period but also finds a significant change in the total size of the holdings of Canadian fixed income funds. These results strengthen the view that flows were higher in the post-crisis period than during the crisis period, but do not explain the correlation between changes in the asset allocation of fixed income funds during the three periods. Dollar fund flow is positively related to the crisis period, indicating that, during the recession, the dollar fund flow in fixed income funds had a positive value, signifying an inflow. The monthly return follows the same path taken by flow. Institutional investors can use these findings to build an allocation strategy during periods of distress. By showing how the flow size varied for fixed income funds during recessionary times, this study presents a clear picture of the economic environment and depicts levels of variation in returns, offering an accurate snapshot of the debt funds in the industry.

Code availability STATA code available upon editor's request.

\section{Appendix}

Table 10 Exhibit A

\begin{tabular}{|c|c|c|}
\hline Geographic allocation & Asset allocation & Sector allocation \\
\hline Africa and the Middle East & Canadian Equity & Basic Materials \\
\hline Asia/Pacific Rim & Cash and Equivalents & Cash and Cash Equivalent \\
\hline Canada & Domestic Bonds & Consumer Goods \\
\hline European Union & Equity & Consumer Services \\
\hline Japan & Fixed Income & Energy \\
\hline Latin America & Foreign Bonds & Exchange-traded Fund \\
\hline Multi-National & Income Trust Units & Financial Services \\
\hline North America & International Equity & Fixed Income \\
\hline Other & Other & Healthcare \\
\hline Other Asian & U.S. Equity & Industrial Goods \\
\hline Other European & & Industrial Services \\
\hline \multirow[t]{6}{*}{ United States } & & Mutual Fund \\
\hline & & Other \\
\hline & & Real Estate \\
\hline & & Technology \\
\hline & & Telecommunications \\
\hline & & Utilities \\
\hline
\end{tabular}


Table 11 Exhibit B

Canadian equity funds

Global fixed income funds

Canadian Equity \& Income Equity

Global Corporate Fixed Income

Canadian Equity

Global Fixed Income

Canadian Equity Balanced

Global Fixed Income Balances

Canadian Focused Equity

Canadian Focused Small/Mid Cap Equity

Canadian Small/Mid Cap Equity

Canadian Money Markey

Funding Dr. Samarbakhsh acknowledges funding from the Social Sciences and Humanities Research Council of Canada (SSHRC).

Data availability Raw data were purchased from Fundata Inc. The authors are not authorized to share data.

\section{Declarations}

Conflicts of interest/competing interests Not Applicable.

\section{References}

Aggarwal RK, Jorion P (2010) The performance of emerging hedge funds and managers. J Financ Econ 96(2): $238-256$

Bank of Canada. (2019) Selected Bond Yields. Accessed December 1, 2019. https://www.bankofcanada.ca/ rates/interest-rates/canadian-bonds/

Bedendo M, Bruno B (2012) Credit risk transfer in U.S. commercial banks: What changed during the 20072009 crisis? Journal of Banking \& Finance 36 12:3260-3273

Bello, Zakri Y (2008) The performance of U.S. domestic equity mutual funds during recent recessions. Global Journal of Finance and Banking. Issues 3, no. 2

Bers MK, Madura J (2000) The performance persistence of closed-end funds. Financ Rev 35(3):33-52

Blake CR, Elton EJ, Gruber MJ (1993) The performance of bond mutual funds. J Bus 66:371-403

Canadian Investment Funds Standards Committee (2017) Mutual funds. Accessed August 10, 2020. http:// www.cifsc.org/

Cao C, Chang EC, Wang Y (2008) An empirical analysis of the dynamic relationship between mutual fund flow and market return volatility. J Bank Financ 32(10):2111-2123

Clare A, O'Sullivan N, Sherman M, Zhu S (2019) The performance of U.S. bond mutual funds. Int Rev Financ Anal 61:1-8

Cornell B, Green K (1991) The investment performance of low-grade bond funds. J Financ 46(1):29-48

Coval J, Stafford E (2007) Asset fire sales (and purchases) in equity markets. J Financ Econ 86(2):479-512

Cumby RE, Glen JD (1990) Evaluating the performance of international mutual funds. J Financ 45(2):497521

Del Guercio D, Tkac PA (2002) The determinants of the flow of funds of managed portfolios: Mutual funds vs. pension funds. Journal of Financial and Quantitative Analysis 37(4):523-557

Del Guercio D, Tkac PA (2008) Star power: the effect of monrningstar ratings on mutual fund flow. J Financ Quant Anal 43(4):907-936

Droms WG, Walker DA (1994) Investment performance of international mutual funds. J Financ Res 17(1):114 
Edwards FR, Zhang X (1998) Mutual funds and stock and bond market stability. J Financ Serv Res 13(3): $257-282$

Elton EJ, Gruber MJ, Blake CR (1996) Survivor bias and mutual fund performance. Rev Financ Stud 9(4): $1097-1120$

Fundata Canada Inc. (2019) Canadian mutual fund, ETF and stock data provider | Fundata Canada Inc. Fundata Canada Inc. Accessed September 10, 2019. http://www.fundata.com/

Glode V (2011) Why mutual funds "underperform". J Financ Econ 99(3):546-559

Helppie McFall, B. (2011). Crash and wait? The impact of the Great Recession on the retirement plans of older Americans. American Economic Review, 101(3), 40-44

Huij J, Derwall J (2008) "hot hands" in bond funds. J Bank Financ 32(4):559-572

Investment Company Institute. (2019). Annual report for members. Accessed November 15, 2019. https:// www.ici.org/pubs/annuals

Ippolito RA (1989) Efficiency with costly information: A study of mutual fund performance, 1965-1984. The Quarterly Journal of Economics 104(1):1-23

Kaminsky G, Lyons R, Schmukler S (2001) Mutual fund investment in emerging markets: an overview. International financial contagion. Springer, Boston, MA, pp 157-185

Kamstra MJ, Kramer LA, Levi MD, Wermers R (2017) Seasonal asset allocation: evidence from mutual fund flows. J Financ Quant Anal 52(1):71-109

Kolokolova O, Lin M-T, Poon S-H (2020) Too big to ignore? Hedge fund flows and bond yields. J Bank Financ 112:105271

Leite P, Armada MR (2017) Bond fund performance during recessions and expansions: Empirical evidence from a small market. International Review of Finance 17(1):163-170

Moore GH (1983) Security markets and business cycles. n Business Cycles, Inflation, and Forecasting, 2nd edition, pp. 139-160. Ballinger

Otten R, Bams D (2002) European mutual fund performance. Eur Financ Manag 8(1):75-101

Rakowski D (2010) Fund flow volatility and performance. J Financ Quant Anal 45(1):223-237

Rakowski D, Wang X (2009) The dynamics of short-term mutual fund flows and returns: a time-series and cross-sectional investigation. J Bank Financ 33(11):2102-2109

Statistics Canada. (2019). Table 10-10-0122-01 Financial Market Statistics. Accessed November 30, 2019. https://www150.statcan.gc.ca/t1/tbl1/en/tv.action?pid=1010012201

Zenteno, M. \& Aquino, J. (2020, May 1). Canada mutual funds post record redemptions as COVID-19 worries grow. Retrieved August 13, 2020, from https://rsmcanada.com/our-insights/coronavirus-resourcecenter/canada-mutual-funds-post-record-redemptions-as-covid-19-worries-.html

Publisher's note Springer Nature remains neutral with regard to jurisdictional claims in published maps and institutional affiliations. 